\title{
Atrazine and 2, 4-D Determination in Corn Samples Using Microwave Assisted Extraction and On-line Solid-phase Extraction Coupled to Liquid Chromatography
}

Ana Susana Santos-Hernández, Laura Hinojosa-Reyes, Isabel del Carmen Sáenz-Tavera, Aracely Hernández-Ramírez, Jorge Luis Guzmán-Mar*

Universidad Autónoma de Nuevo León, UANL, Facultad de Ciencias Químicas, Cd. Universitaria, San Nicolás de los Garza, Nuevo León, C.P. 66455, México.

*Corresponding author: Jorge Luis Guzmán-Mar. e-mail address: jorge.guzmanmr@uanl.edu.mx

Received February 2 ${ }^{\text {nd }}$, 2018; Accepted March $4^{\text {th }}, 2018$.

DOI: http://dx.doi.org/10.29356/jmcs.v62i2.475

\begin{abstract}
In this study, on-line sample pretreatment (clean-up and analyte preconcentration) using sequential injection analysis was coupled to high performance liquid chromatography with UV detection (HPLC/UV) for the determination of 2,4-D (2,4-dichlorophenoxyacetic acid) and atrazine in corn samples. Prior to their analysis, microwave-assisted extraction approach for 2,4-D and atrazine in corn samples was carried out using MeOH: $\mathrm{H}_{2} \mathrm{O}(30: 70 \mathrm{v} / \mathrm{v})$ solvent at $50^{\circ} \mathrm{C}$ for $20 \mathrm{~min}$. The on-line SPE-HPLC/UV approach combined reversed solid-phase extraction using Strata X sorbent with $\mathrm{MeOH}: \mathrm{H}_{2} \mathrm{O}(80: 20 \mathrm{v} / \mathrm{v})$ at $1 \mathrm{~mL}$ $\mathrm{min}^{-1}$ as eluent for the enrichment of the analytes. C18 monolithic column with ACN: $10 \mathrm{mM}$ $\mathrm{CH}_{3} \mathrm{COOH} / \mathrm{CH}_{3} \mathrm{COONa}$ buffer at $\mathrm{pH} 4\left(20: 80\right.$, v/v) was employed as mobile phase at $2 \mathrm{~mL} \mathrm{~min}^{-1}$ flow rate for chromatographic separation of the compounds before UV detection. Enrichment factors up to 13.4 were achieved with a $10 \mathrm{~mL}$ sample volume. The developed procedure showed linear response ranges from $0.07-$ $0.70 \mathrm{mg} \mathrm{kg}^{-1}$ for 2,4-D and atrazine with correlation coefficients $>0.993$. The LODs were 0.03 and $0.02 \mathrm{mg}$ $\mathrm{kg}^{-1}$ for 2,4-D and atrazine, respectively with RSD ranged from 4.0 to $7.2 \%$ at concentration level of 0.07 and $0.30 \mathrm{mg} \mathrm{kg}^{-1}$. The extraction recoveries of 2,4-D and atrazine in corn samples were from 82.6 to $98.2 \%$. The proposed method showed good recoveries and reasonable precision for herbicide analysis in corn samples avoiding the time-consuming batch sample pretreatment step, and thus minimizing risks of sample contamination and analyte losses.
\end{abstract}

Key words: herbicide; corn; microwave assisted extraction; on-line SPE-HPLC/UV.

Resumen. En este estudio, el pretratamiento en línea de la muestra (limpieza y preconcentración del analito) utilizando un sistema de análisis por inyección secuencial acoplado cromatografía de líquidos con detección UV (HPLC/UV) se propuso para la determinación de 2,4-D (ácido 2,4-diclorofenoxiacético) y atrazina en muestras de maíz. Previo al análisis, se desarrolló un procedimiento de extracción asistida por microondas para 2,4-D y atrazina en muestras de maíz utilizando como solvente $\mathrm{MeOH}: \mathrm{H}_{2} \mathrm{O}\left(30: 70\right.$, v/v) a $50^{\circ} \mathrm{C}$ durante 20 min. El acoplamiento en línea del sistema SPE-HPLC/UV combinó la extracción en fase sólida utilizando el adsorbente Strata X y como eluente $\mathrm{MeOH}: \mathrm{H}_{2} \mathrm{O}\left(80: 20\right.$, v/v) a un caudal de $1 \mathrm{~mL} \mathrm{~min}^{-1}$. Para la separación cromatográfica de los analitos previo a la detección UV se empleó una columna monolítica de tipo C18, la fase móvil fue ACN:Buffer $\left(\mathrm{CH}_{3} \mathrm{COOH} 10 \mathrm{mM} / \mathrm{CH}_{3} \mathrm{COONa}\right.$ a pH 4, 20:80, v/v) a un caudal de $2 \mathrm{~mL} \mathrm{~min}^{-1}$. Se lograron factores de enriquecimiento de hasta 13.4 con un volumen de muestra de 10 $\mathrm{mL}$. El procedimiento desarrollado mostró rangos de respuesta lineal entre $0.07-0.70 \mathrm{mg} \mathrm{kg}^{-1}$ para 2,4-D y atrazina con coeficientes de correlación $>0.993$. Los LOD fueron de 0.03 y $0.02 \mathrm{mg} \mathrm{kg}^{-1}$ para el 2,4-D y la atrazina, respectivamente con RSD que varió de 4.0 a $7.2 \%$ a un nivel de concentración de 0.07 y $0.30 \mathrm{mg}$ $\mathrm{kg}^{-1}$. Las recuperaciones obtenidas por la extracción asistida por microondas de 2,4-D y atrazina en muestras de maíz fueron de 82.6 a $98.2 \%$. El método propuesto mostró recuperaciones aceptables y una precisión razonable para el análisis de herbicidas en muestras de maíz, evitando los inconvenientes en la etapa de pretratamiento de muestra tradicional, que consume mucho tiempo, y por lo tanto se minimiza los riesgos de contaminación y pérdidas de analitos en la muestra.

Palabras clave: herbicida; maíz; extracción asistida por microondas; sistema en línea SPE-HPLC/UV. 


\section{Introduction}

Herbicides are widely used in agriculture for weed management and significantly contribute to increased crop yields and economic returns [1]. The 2,4-D (2,4-dichlorophenoxyacetic acid) is a member of the chlorophenoxy acid herbicides that has been used to selectively control broadleaf weeds in wheat, corn, cotton, soybean, and tobacco crops. Currently, its annual usage ranks seventh among herbicides in agricultural markets [2]. On the other hand, atrazine (2-chloro-4-(ethylamine)-6-(isopropyl amine)-striazine) is a member of the triazine family and it has been classified as a human carcinogen [3]. Atrazine is applied to wheat, corn, barley, legumes, and several fruit crops. Although this pesticide was prohibited in the European Union in 2004, it is still one of the most widely used herbicides in the world [4]. As the result of extensive use of 2,4-D and atrazine for agricultural purposes, their application and usage have become a widespread environmental problem [5]. The European legislation has set in corn the maximum residue level (MRL) for 2,4-D as $0.05 \mathrm{mg} \mathrm{kg}^{-1}$ while for atrazine this level is $0.25 \mathrm{mg} \mathrm{kg}^{-1}$ [3, 6]. Maize (Zea mays) is one of the most important cereal grains in the world, it serves as a staple food for approximately 400 million people in developing countries, and it is used as a food ingredient and animal feed [7]. Therefore, a simple, rapid and sensitive analytical method for determination of 2,4-D and atrazine in agriculture products, is of particular imprtance. Gas chromatography with mass spectrometry (GC-MS), liquid chromatography- with mass spectrometry (LC-MS) and high-performance liquid chromatography with UV detection (HPLC) are commonly used instrumental methods to measure these herbicides in cereal crops, soil, and environmental water samples [7, 8, 9, 10, 11, 12]. HPLC with UV detection has the advantages of simplicity, and low cost in comparison with MS techniques. The extraction and preconcentration protocols along with these analytical methods are essential to achieving quality of the analytical data related to low levels of these herbicides in corn samples. Sample preparation for pesticide analysis in environmental samples usually requires liquid-liquid extraction (LLE) or solid phase extraction (SPE) techniques to clean up and to concentrate the target analyte [8, 10, 13, 14, 15]. The conventional LLE often needs large amounts of toxic solvent and a time-consuming procedure, while SPE is simple, fast and consumes very small volumes of high purity solvents. Thus, SPE is the most suitable enrichment method for pesticide analysis in environmental matrices and it can be easily automated by online coupling with HPLC systems simplifying the operations carried out by the analyst and offers further advantages, such as small sample volumes, minimal amount of solvents required for extraction, while yielding comparable method detection limits [16, 17, 18, 19]. For SPE systems have to find the appropriate sorbent material for the analytical problem. Modified polymeric sorbents are good alternative for SPE because are functionalized with specific ligands to give retention of analyte molecules. Strata $\mathrm{X}$ is a surface modified styrene skeleton with $\mathrm{N}$-vinylpyrrolidone functional groups, whose retention mechanisms are hydrophobic, hydrogen bonding and aromatic. This sorbent can be applied to the reversed phase extraction of acidic, basic, and neutral compounds [18, 19, 20].

Due to complex nature of the matrices in which the target compounds are present, an extraction procedure that provides suitable recovery for the analytes is an important aspect to develop analytical methods. Recent studies have shown the applicability of microwave assisted extraction (MAE) for the determination of pesticides in environmental samples [21, 22, 23]. In comparison to other extraction procedures, MAE shows several advantages due to its speed, simplicity, low consumption of sample and solvent, compatibility of polar solvents used with LC technique and high extraction efficiency [24].

The aim of this work was to develop an automated method for determining 2,4-D and atrazine in corn samples by on-line solid-phase extraction coupled to high performance liquid chromatography with UV detection (SPE-HPLC/UV). Further, a simple and rapid MAE method for extraction of 2,4-D and atrazine herbicides from corn samples has been proposed. The experimental parameters which might affect the extraction efficiency as extraction temperature, time, extracting solvent and solvent composition, were evaluated. The method was applied to analyze these compounds in corn samples.

\section{Experimental}

\section{Materials and Chemicals}

Atrazine (98.8 \% purity) and 2,4-D (98\% purity) were purchased from Pestanal ${ }^{\circledR}$ Fluka, SigmaAldrich. HPLC-grade methanol (99.8\%), phosphoric acid (85\%) and anhydrous copper sulfate $\left(\mathrm{CuSO}_{4}\right.$, 98.5\%) were from JT Baker. Acetic acid glacial (99\%), sodium acetate (99\%), and acetone (99.96\%) were purchased from Sigma-Aldrich. The sorbent Strata X a reversed phase copolymer of styrene- 
divinylbenzene with modified surface of an average particle size of $33 \mu \mathrm{m}$ and pore diameter $85 \AA$ was from Phenomenex Inc. Water was purified with a Milli-Q $(18 \mathrm{M} \Omega . \mathrm{cm})$ purification system (Millipore, Billerica, MA, USA). Stock solutions of 30 and $100 \mathrm{mg} \mathrm{L}^{-1}$ of atrazine and 2,4-D were prepared by dissolving the appropriate amount of the compounds in $4 \%(\mathrm{v} / \mathrm{v})$ methanol in water and water, respectively. The stock solutions were conserved at $4{ }^{\circ} \mathrm{C}$ and used for no longer than 3 months. Evaluation of the preconcentration step conditions was carried out using standard solution containing $1.0 \mathrm{mg} \mathrm{L}^{-1}$ of 2,4-D and atrazine. A methanol: water mix $\left(\mathrm{MeOH}: \mathrm{H}_{2} \mathrm{O}, 80: 20\right.$, v/v) was used for washing and conditioning the SPE column.

\section{Sample preparation}

White waxy corn sample was purchased from local supermarket in Monterrey, México. The sample was pulverized using a grain mill (Electric mil 1/2 Hp, Molinos del Rey) and passed through an 80mesh sieve to obtain the powered sample. The fortified corn sample containing 2,4-D and atrazine herbicides was prepared by spiking the stock standard solutions at concentration level of $6 \mathrm{mg} \mathrm{L}^{-1}$, respectively into $10 \mathrm{~g}$ of milled corn and shaking for $3 \mathrm{~min}$. To ensure the herbicides to be well distributed, a reasonable amount of acetone was added to moisten the milled corn. The sample was homogenized with constant stirring at room temperature during $90 \mathrm{~min}$ and then the solvent was evaporated to dryness on a rotary evaporator under vacuum (Yamato RE500). Sample was stored refrigerated at $4{ }^{\circ} \mathrm{C}$ before extraction of the herbicides.

\section{Flow manifold and on-line SPE-HPLC/UV analysis}

The manifold used for the automatization of on-line SPE-HPLC/UV is shown schematically in Fig. 1. A fully automated method based on solid phase extraction (SPE) using a Sequential Injection Analysis (SIA) (multisyringe module BU-4S, Crison Instruments; Alella, Barcelona, Spain) with one $5 \mathrm{~mL}$ syringe (S1), Hamilton, Bonaduz, Switzerland) containing a selection valve (8-port multi-position selection valve) and injection valve (MPV and IV, Crison Instruments, Alella, Barcelona, Spain). All these connectors were made from poly(methyl methacrylate) (PMMA). The manifold was made of Teflon tubing (0.8 and $1.5 \mathrm{~mm}$ i.d.). The SPE was coupled to a high pressure HPLC pump (HPLC YL9200 Single Pump, YL Instrument CO., LTD, Korea). The detection system consisted of a deuterium light source (DT-1000CE; Analytical Instrument System, Flemington, NJ, USA) and a USB2000 CCD spectrophotometer (Ocean Optics, Dunedin, FL, USA) connected through a flow-through quartz cell (178.710-QS, Hellma, NY, USA). Autoanalysis v5.0 software (Sciware, Palma de Mallorca, Spain) was used for instrument control, data acquisition, and data processing.

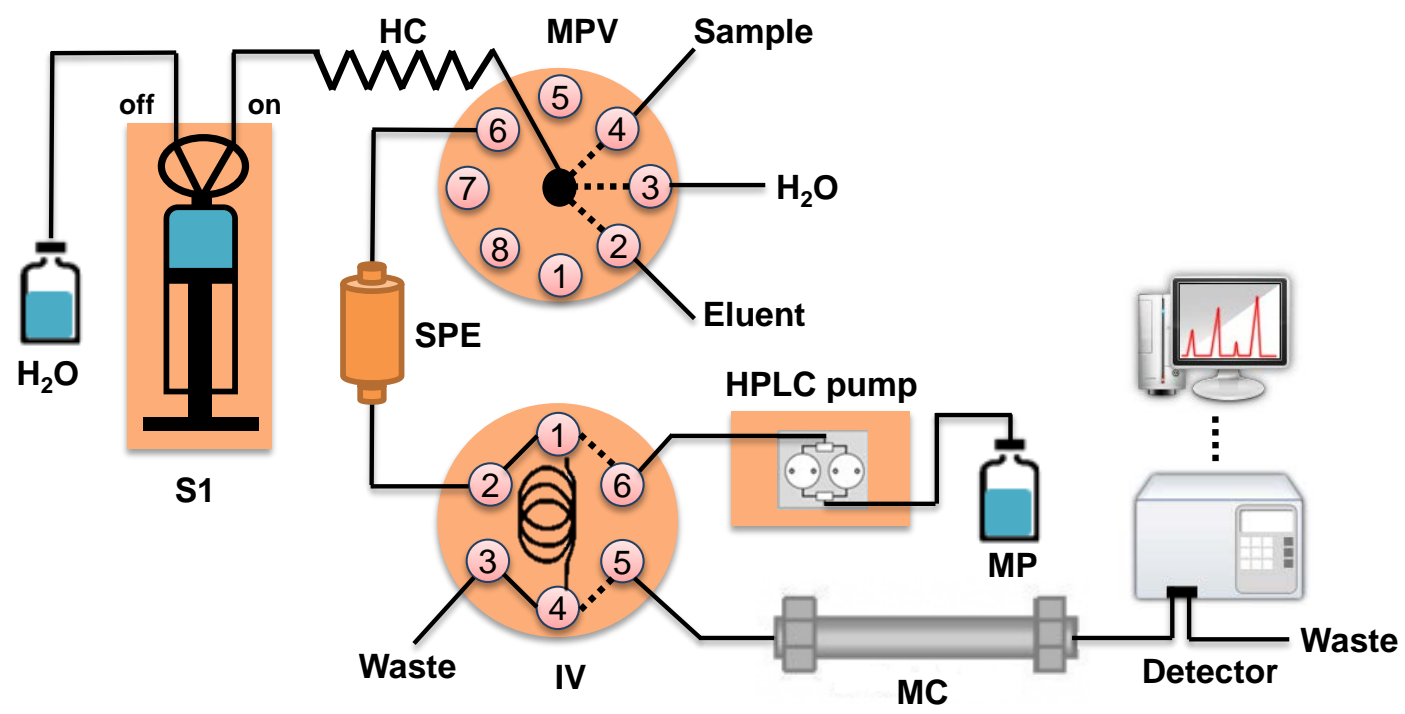

Fig. 1. Manifold used for the on-line SPE in combination with HPLC-UV equipment for the determination of 2,4-D and atrazine in corn samples. S1: syringe, HC: holding coil, MPV: multi-position valve, SPE: solid phase extraction, IV: injection valve, MP: mobile phase, MC: monolithic column. 
The system (Fig. 1.) was operated according to the sequence described in Table 1. A mini-column $(10 \times 4 \mathrm{~mm}$ i.d.) packed with $30 \mathrm{mg}$ of Strata X sorbent was used for solid phase extraction (SPE) procedure. The column was made of PMMA and contained glass wool at both ends to prevent losses of sorbent during preconcentration/elution steps. Initially the SPE column was conditioned with $1 \mathrm{~mL}$ of $\mathrm{MeOH}: \mathrm{H}_{2} \mathrm{O}(80: 20$ $\mathrm{v} / \mathrm{v}$ ) and $1 \mathrm{~mL}$ of water (steps 1 to 4 ). Then, $10 \mathrm{~mL}$ of the sample solution was passed through the SPE column at $1 \mathrm{~mL} \mathrm{~min}^{-1}$ flow rate (steps 5 and 6). After adsorption of herbicides by the SPE sorbent, the elution of the analytes from the SPE was performed with $\mathrm{MeOH}: \mathrm{H}_{2} \mathrm{O}\left(80: 20\right.$, v/v) at $1 \mathrm{~mL} \mathrm{~min}^{-1}$ using a volume of $0.5 \mathrm{~mL}$ and filling the loop of the HPLC injection valve (step steps 7 and 8 ). The chromatographic separation of 2,4-D and atrazine eluted from the SPE column was performed on an Onyx ${ }^{\mathrm{TM}} \mathrm{RP}-18$ monolith column $(25 \times 4.6 \mathrm{~mm}$, MC, Phenomenex, USA) with a $10 \times 4.6 \mathrm{~mm}$ monolithic guard column with. The mobile phase was ACN: $10 \mathrm{mM}$ buffer of $\mathrm{CH}_{3} \mathrm{COOH} / \mathrm{CH}_{3} \mathrm{COONa}$ at $\mathrm{pH} 4$ (20:80, v/v, MP) using a flow rate of $2 \mathrm{~mL} \mathrm{~min}^{-1}$ and the injected volume was $100 \mu \mathrm{L}$. Detection was simultaneously carried out at the absorption maximum of 2,4-D (230 nm) and atrazine $(223 \mathrm{~nm})$. Measurements were based on the peak heights. Baseline separation of 2,4-D and atrazine was carried out within $5 \mathrm{~min}$. The retention time of these analytes were 0.9 and $2.7 \mathrm{~min}$, respectively. Quantification of the analytes was based on external standard calibration using linear regression analysis. The extraction recoveries of 2,4-D and atrazine in corn samples were determined in fortified samples. The extraction of the compounds from this matrix was carried out by MAE procedure followed by their analysis by on-line SPE coupled to HPLC/UV system. All experiments were done in triplicate. The reusability of Strata-X sorbent used for SPE column was 5 cycles without loss of recoveries for 2,4-D and atrazine.

Table 1. Protocol sequence to automate the on-line SPE- HPLC/UV for herbicides determination in corn samples.

\begin{tabular}{|c|c|c|c|c|c|}
\hline Step & Description & $\begin{array}{l}\text { MPV } \\
\text { Position }\end{array}$ & $\begin{array}{l}\text { IV } \\
\text { Position }\end{array}$ & $\begin{array}{l}\text { Volume } \\
(\mathrm{mL})\end{array}$ & 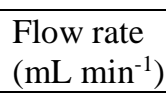 \\
\hline 1 & Loading the sorbent conditioning solution for SPE column & 2 & $2-1,4-3$ & 1 & 5 \\
\hline 2 & Dispense the sorbent conditioning solution into SPE column & 6 & $2-1,4-3$ & 1 & 1 \\
\hline 3 & Loading water for washing sorbent & 3 & $2-1,4-3$ & 1 & 5 \\
\hline 4 & Dispense water into the SPE for washing sorbent & 6 & $2-1,4-3$ & 1 & 1 \\
\hline 5 & Loading sample in $\mathrm{HC}^{1}$ & 4 & $2-1,4-3$ & 10 & 5 \\
\hline 6 & Dispense sample into SPE column ${ }^{1}$ & 6 & $2-1,4-3$ & 10 & 1 \\
\hline 7 & Loading eluent in $\mathrm{HC}$ & 2 & $2-1,4-3$ & 0.5 & 5 \\
\hline 8 & Dispense eluent into SPE column & 6 & $2-1,4-3$ & 0.5 & 1 \\
\hline 9 & Start HPLC pump and detection & 6 & $6-1,4-5$ & 5 & 1 \\
\hline 10 & Obtaining the chromatogram & & & & \\
\hline 11 & Stop HPLC pump and detection & 6 & $6-1,4-5$ & 0 & 0 \\
\hline 12 & The system is ready to start again & & & & \\
\hline
\end{tabular}

${ }^{1}$ The step was repeated twice due to syringe capacity $(5 \mathrm{~mL})$.

\section{Microwave assisted extraction procedure}

The extraction of 2,4-D and atrazine from corn samples was conducted in a microwave extraction system (Mars 6, CEM, USA) equipped with Teflon ${ }^{\circledR}$ TFM $100 \mathrm{~mL}$ extraction vessels. Approximately 500 mg of fortified corn sample was accurately weighed and transferred into the microwave Teflon vessel, and then, $20 \mathrm{~mL}$ of $\mathrm{MeOH}: \mathrm{H}_{2} \mathrm{O}\left(30: 70\right.$, v/v) were added to the sample. The sample was extracted at $50^{\circ} \mathrm{C}$ for $20 \mathrm{~min}$ operated at $600 \mathrm{~W}$ output, and then, the extracts were centrifuged at $4000 \mathrm{rpm}$ for $10 \mathrm{~min}$. Subsequently, the supernatant was transferred to polypropylene tube, and $2 \mathrm{~mL}$ of $2 \%\left(\mathrm{w} / \mathrm{v}\right.$ ) $\mathrm{CuSO}_{4} \mathrm{was}$ added for protein precipitation [25]. The resulting mixture was vortex-mixed for 2 min, followed by 10 min centrifugation at $4000 \mathrm{rpm}$. The final supernatant was transferred and diluted to $25 \mathrm{~mL}$ with water and then ready for clean-up and preconcentration step by on-line SPE method. All extractions were performed in triplicate. The method blank was evaluated throughout the entire extraction procedure. In order to find the most significant variables for MAE, $3^{2}$ full factorial design was built resulting in 11 experiments. Experimental design calculations were performed by using the software Statistica 8.0 (StatSoft, Inc., www.statsoft.com). 


\section{Results and Discussion}

In the present study, the applicability of the on-line SPE combined with HPLC-UV was considered for the determination of 2,4-D and atrazine in corn samples. There are several factors that can affect the preconcentration step including the type of sorbent and its amount, the eluent volume, and flow rate were evaluated

\section{On-line solid phase extraction}

The SPE-HPLC/UV manifold presented in Fig. 1 enabled on-line transfer of a pretreated sample to the chromatographic column, according to the steps showed in Table 1. The SPE optimization started with selection of adequate sorbent taking into consideration physicochemical properties of the analytes and matrix together with their possible interactions with the sorbent. A Strata X modified polymeric sorbent was selected for the extraction of herbicide compounds since this hydrophilic sorbent can interact with aromatic analytes via $\pi-\pi$ interactions $[18,19,20]$. Atrazine and $2,4-\mathrm{D}$ are relatively strong acids; while atrazine has a pKa value of 1.60 , pKa value of 2,4-D is $2.73[17,26]$. The $\mathrm{pH}$ of sample solution was not adjusted during the preconcentration step showing a natural $\mathrm{pH}$ of approximately 6.5 units. Their retention on Strata $\mathrm{X}$ sorbent was not $\mathrm{pH}$ dependent in the $\mathrm{pH} \geq 3$ since under these conditions, both herbicides primarily existed in an anionic state. For the determination of polar contaminants as the atrazine herbicide in wastewater and surface water, Singer et al. used Strata-X sorbent for the enrichment of the analytes at pH 4 [18]. García-Ac et al. quantified 14 trace organic contaminants as atrazine in drinking and surface water using Strata-X for the preconcentration of the target analytes in acidic medium [19]. Biesaga et al determined phenoxyalkanoic acid herbicides including 2,4-D in water samples. The enrichment of the analytes was carried out without acidification using different sorbents as Strata X [20].

Amount of sorbent. The influence of the amount of Strata X sorbent on the extraction recoveries of 2,4-D and atrazine was investigated by varying the amount of sorbent from 15 to $45 \mathrm{mg}$. As shown in Fig. 2a, good recoveries for both herbicides were achieved using sorbent amount of 15 and $30 \mathrm{mg}$. However, further increase in the amount of sorbent was not significantly improved the recovery percentages of these compounds. Therefore, $30 \mathrm{mg}$ of sorbent was employed for subsequent experiments since an increase in the number of binding sites of the sorbent could allow the selective extraction and clean-up of these herbicides from complex samples as corn.

Composition of the eluent. The elution solvent is one of the most important parameter to control in the development of the on-line SPE procedure. Although chromatographic separation was carried out using acetonitrile as organic modifier in the mobile phase, methanol is compatible with the connectors used in SPE manifold and this solvent has been commonly used for the elution of polar organic compounds from Strata-X sorbent $[18,19]$. The percentage of methanol used in the elution of the target compounds from the sorbent was varied between 40 and $80 \%$, as is seen in Fig. 2b. It was eventually found that $\mathrm{MeOH}: \mathrm{H}_{2} \mathrm{O}(80: 20$, v/v) provided an effective elution of 2,4-D and atrazine from the Strata X sorbent. The effect of eluent volume (between 0.3 and $1 \mathrm{~mL}$ ) on the recovery of the herbicides was also studied. Quantitative recoveries (recovery percentages above 95\%) were obtained with $0.5 \mathrm{~mL}$ of $\mathrm{MeOH}: \mathrm{H}_{2} \mathrm{O}$ (80:20, v/v) for $30 \mathrm{mg}$ sorbent. Therefore, volume of $0.5 \mathrm{~mL}$ of eluent for desorption of the compounds was used in the remaining experiments. The influence of the eluent flow rate on herbicide recoveries was also studied. The flow rate during the preconcentration and elution steps was set at $1 \mathrm{~mL} \mathrm{~min}^{-1}$ to avoid overpressure of the on-line SPE system.

Sample loading volume. In the analysis of real samples, the sample volume is one of the important parameters affecting the preconcentration factor. Therefore, the maximum sample volume was investigated by increasing the volume of the solution containing a mixture of herbicides 2,4-D and atrazine at concentration of $1 \mathrm{mg} \mathrm{L}^{-1}$ each one. Sample volumes of 2, 4, 6, 8, 10 and $12 \mathrm{~mL}$ containing this herbicide mixture were passed through the column. The results in Fig. 2c demonstrated that quantitative recoveries of 2,4-D and atrazine on Strata-X sorbent were obtained for sample volume up to $10 \mathrm{~mL}$. 

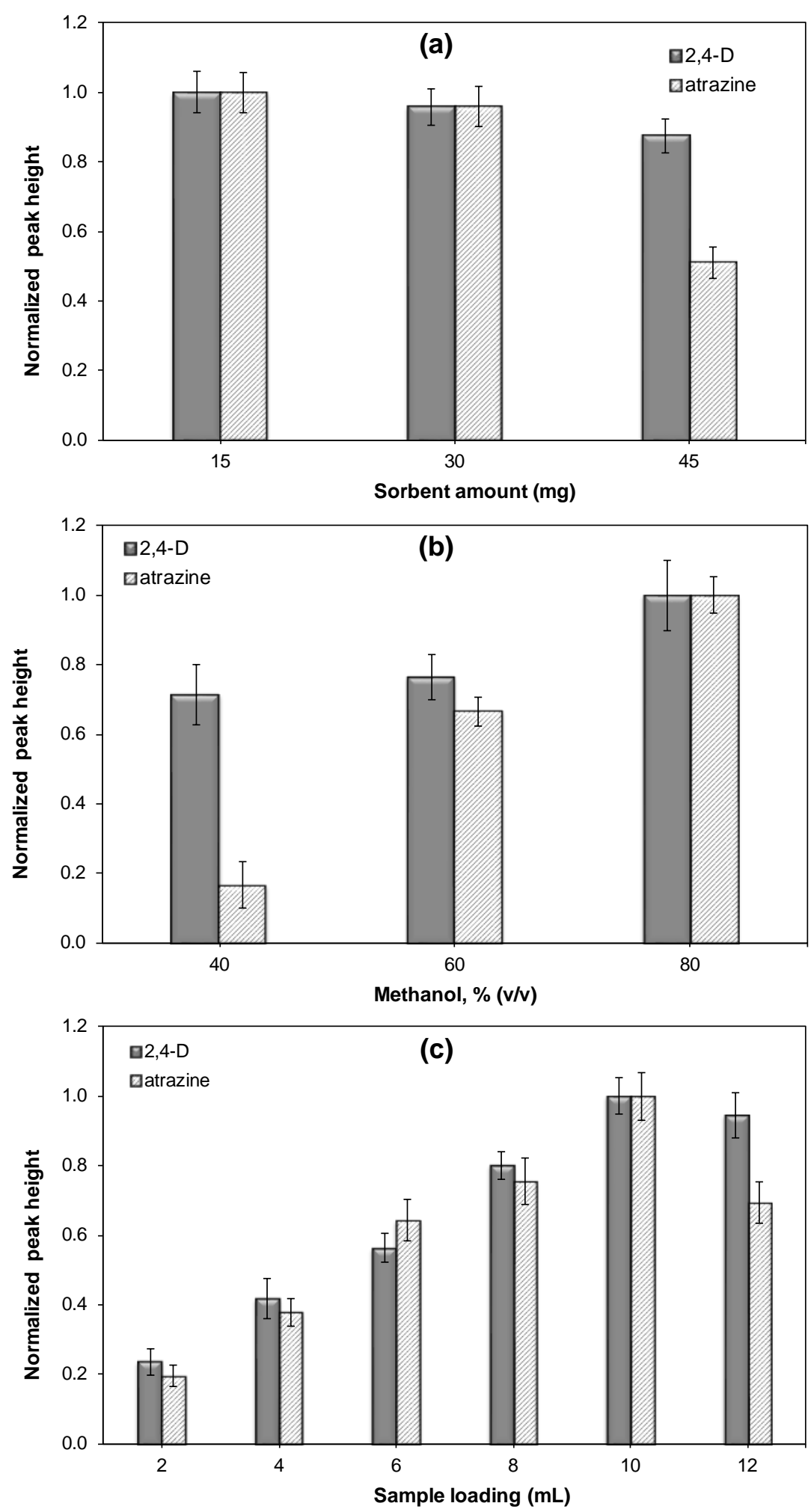

Fig. 2. The effect of (a) the sorbent amount, (b) methanol content in the eluent and (c) sample loading volume on the normalized peak height intensity. (Conditions: herbicides concentration; $1 \mathrm{mg} \mathrm{L}^{-1}$, eluent;

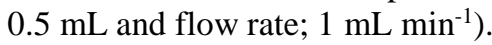




\section{Analytical performance of the on-line SPE -HPLC/UV method.}

The analytical performance obtained via this on-line SPE-HPLC/UV is summarized in Table 2. The method was evaluated by its linearity, sensitivity and precision. Seven-point standard curves were constructed by on-line analysis of standard solutions injected by triplicate in the range of $0.07-0.70 \mathrm{mg}$ $\mathrm{kg}^{-1}$ for 2,4-D and atrazine. Calibration graphs showed good correlations for the two analytes with linear correlation coefficients $>0.993$. The limits of detection (LODs) and quantification (LOQs) were calculated as three and ten times, respectively, the standard deviation of ten blank samples divided by the slope of the calibration curve. The LODs were 0.03 and $0.02 \mathrm{mg} \mathrm{kg}^{-1}$ for 2,4-D and atrazine. The LOD for atrazine was 10 times lower than previously reported value for triazines herbicides by magnetic nanoparticle assisted supramolecular solvent extraction prior to their determination by HPLC/UV [27]. Comparable LODs for 2,4-D and atrazine were obtained by multisyringe chromatography coupled to on-line SPE analysis using membrane extraction disks for the on-line enrichment of these organic compounds [17]. The relative standard deviations (RSDs) at two level concentrations of 0.07 and $0.30 \mathrm{mg} \mathrm{kg}^{-1}$ were assessed by ten replicate measurements and ranged from 4.0 to $7.2 \%$. The enrichment factors were in the range of $12.0-$ 13.4 (Table 2), which were calculated from the slope ratio of the aqueous calibration curves obtained through the on-line SPE -HPLC/UV and from the HPLC/UV system without preconcentration step.

Table 2. Analytical performance of the on-line SPE- HPLC/UV.

\begin{tabular}{|l|c|c|}
\hline \multicolumn{1}{|c|}{ Parameter } & 2,4-D & atrazine \\
\hline Lineal equation & $\mathrm{y}=0.071 \mathrm{x}+0.0098$ & $\mathrm{y}=0.1647 \mathrm{x}+0.0018$ \\
\hline Correlation coefficient $(\mathrm{r})$ & 0.9936 & 0.9990 \\
\hline Lineal range $\left(\mathrm{mg} \mathrm{L}^{-1}\right)$ & $0.07-0.7$ & $0.07-0.7$ \\
\hline \multirow{2}{*}{$\mathrm{RSD}(\%)$} & $5.7\left(0.07 \mathrm{mg} \mathrm{L}^{-1}\right)$ & $7.2\left(0.07 \mathrm{mg} \mathrm{L}^{-1}\right)$ \\
\cline { 2 - 3 } & $6.0\left(0.3 \mathrm{mg} \mathrm{L}^{-1}\right)$ & $4.0\left(0.3 \mathrm{mg} \mathrm{L}^{-1}\right)$ \\
\hline LOD $\left(\mathrm{mg} \mathrm{L}^{-1}\right)$ & 0.03 & 0.02 \\
\hline LOQ $\left(\mathrm{mg} \mathrm{L}^{-1}\right)$ & 0.10 & 0.10 \\
\hline Enrichment factor & 12.0 & 13.4 \\
\hline
\end{tabular}

\section{Microwave assisted extraction method}

In the study, some preliminary experimental parameters that affect the extraction recoveries of 2,4$\mathrm{D}$ and atrazine from corn sample by MAE were investigated. All experiments were carried out by using 0.5 $\mathrm{g}$ of fortified corn sample, $20 \mathrm{~mL}$ volume of extractant solvent at $60{ }^{\circ} \mathrm{C}$.

Solvent. Polar extractants including $\mathrm{MeOH}: \mathrm{H}_{2} \mathrm{O}(50: 50$, v/v) mixture, $\mathrm{MeOH}$ and ACN were evaluated for the extraction of the analytes during $20 \mathrm{~min}$ of irradiation time. Physical-chemical properties of selected solvent, such as boiling point, polarity and density influence the penetration into the sample matrix allowing a more efficient extraction of the analytes [28]. As can be seen in Fig. 3a, the best recoveries of both herbicides were achieved with methanol as the extraction solvent. This result could be due to methanol has a relatively higher dissipation factor, which means that it could transform microwave energy into heat better than other solvents [29, 30]. And the effect of the methanol concentration in the extraction solvent was also studied in this preliminary evaluation, $\mathrm{MeOH}: \mathrm{H}_{2} \mathrm{O}(50: 50$, v/v) provided the higher relative recoveries of both analytes.

Extraction time. To evaluate the extraction time, herbicides were extracted from the fortified corn sample using MeOH: $\mathrm{H}_{2} \mathrm{O}(50: 50$, v/v) at 5, 15 and 25 min. The results (Fig. 3b) did not show difference in atrazine concentration of samples extracted at the evaluated extraction times and 5 min was sufficient for the extraction of this compound. However, 2,4-D extraction efficiency increased as the extraction time increased allowing its maximum recovery at $15 \mathrm{~min}$. Thus, to ensure efficient extraction of both analytes, an extraction time of 20 min was proposed for further experiments. 
Temperature. Temperature is the most important factor evaluated in MAE. The extraction temperature has influence on extraction kinetics and solvent viscosities and therefore also on extraction efficiencies and overall recoveries [29]. The extraction efficiencies were evaluated at three temperatures 60,90 and $120^{\circ} \mathrm{C}$ and the results are shown in Fig. 3c. While the highest extraction efficiency was achieved for atrazine $(83.9 \%)$ at $90^{\circ} \mathrm{C}, 2,4-\mathrm{D}$ showed lower recovery $(48.8 \%)$ at this temperature because it is an easily degradable compound. Furthermore, the use of high temperature may result in more co-extraction of other compounds. Extraction recoveries of approximately $60 \%$ were achieved for atrazine and 2,4-D from fortified corn sample at $60^{\circ} \mathrm{C}$. Thus, it was chosen $60^{\circ} \mathrm{C}$ as the extraction temperature in this preliminary evaluation.
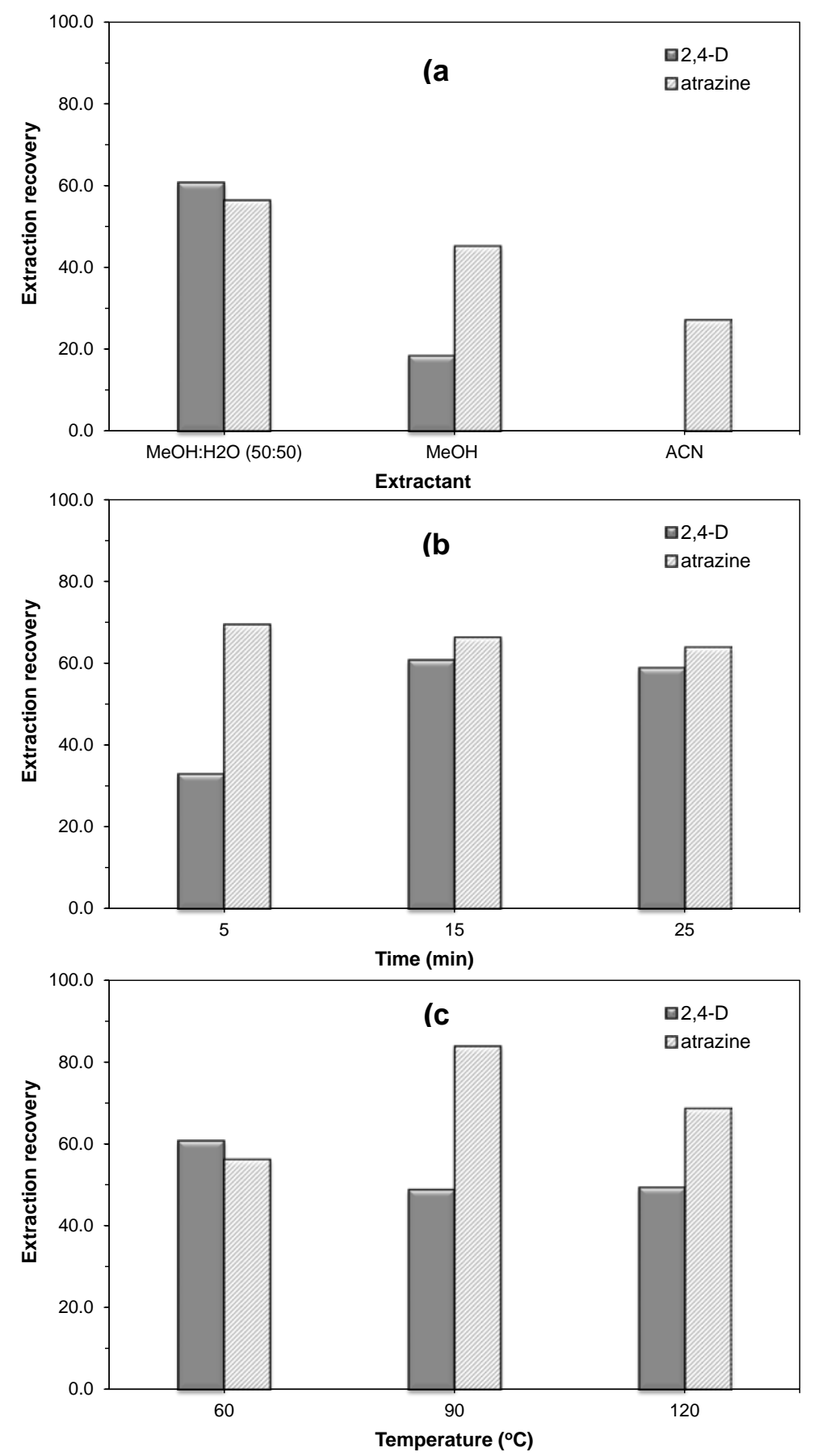

Fig. 3. The effect of (a) solvent, (b) time and (c) temperature on extraction recoveries of herbicides by MAE procedure. 
Full factorial experimental design. In a second step a full factorial experimental design was used for the optimization of the MAE because minimizes the number of experiments, allows to identify important factors affecting the response and explores potential interactions between factors and their effects on system performance [31]. The $3^{2}$ factorial design was conducted to select the optimum values of the variables that have a greater influence on the extraction efficiency: composition of the methanol content in the extractant $(30,50$ and $70 \% \mathrm{v} / \mathrm{v})$ and extraction temperature $\left(50,70\right.$ and $\left.90^{\circ} \mathrm{C}\right)$. This design consisted of 9 factorial points with two replicates of the middle point. The matrix and the results obtained for the $3^{2}$ factorial design is shown in Table 3. The data of this experiment were evaluated by analysis of variance (ANOVA). The Pareto charts (Fig. 4) shows the percentage recoveries for 2,4-D and atrazine. In these charts, the standardized effect of each factor on a response parameter was estimated by comparing the length of its bar. The vertical line on the chart is the critical value that shows whether the effect of a factor is statistically significant at $95 \%$ confidence level. For 2,4-D extraction (Fig. 4a), the temperature was the most significant factor for MAE and 2,4-D recovery percentage increased as extraction temperature decreased. The methanol composition significantly affected the extraction recovery and the extraction increased when decreased methanol content. For atrazine (Fig. 4b), it was observed that both the linear as well as the quadratic terms of methanol composition significantly affected in a negative way the extraction recovery. The desirability function, $\mathrm{D}$, was used to optimize the 2,4-D and atrazine responses. This function was a measure of overall quality and provided a convenient means by which to compare several responses and to select the optimum with the most desirable properties. The scale of the desirability function ranges between $d=0$ for a completely undesirable response to $d=1$ for a fully desired response [31]. The optimization criteria for MAE procedure of the herbicides considered were at optimum value (maximum responses). Fig. 5 shows desirability surface profile that reached its maximum at 0.99 in the region of lower content of methanol and temperature. The optimum values were found methanol composition $30 \%(\mathrm{v} / \mathrm{v})$ and extraction temperature of $50^{\circ} \mathrm{C}$. Extraction experiments using these conditions were carried out to compare the recoveries with the theoretical values reached by the desirability function. The predicted recovery percentages for 2,4-D and atrazine under these extraction conditions was found to be $100 \%$ and $99.2 \%$, while the experimental values ( $\mathrm{n}=3$ replicates) were $99.6 \pm 0.2 \%$ and $97.9 \pm 1.8 \%$. Thus, the results obtained through confirmation experiments indicated the suitability of the developed model.

Table 3. Factorial design matrix $\left(3^{2}\right)$ and the results obtained.

\begin{tabular}{|c|c|c|c|c|}
\hline Experiment & $\begin{array}{l}\text { Methanol content } \\
\text { in extractant }(\mathbf{\%})\end{array}$ & $\begin{array}{l}\text { Temperature } \\
\left({ }^{\circ} \mathbf{C}\right)\end{array}$ & $\begin{array}{l}\text { 2.4-D recovery } \\
(\mathbf{\%})\end{array}$ & $\begin{array}{l}\text { Atrazine recovery } \\
(\mathbf{\%})\end{array}$ \\
\hline 1 & $-(30)$ & $-(50)$ & 100.00 & 97.49 \\
\hline 2 & $0(50)$ & $-(50)$ & 74.79 & 100.00 \\
\hline 3 & $+(70)$ & $-(50)$ & 51.40 & 87.63 \\
\hline 4 & $-(30)$ & $0(70)$ & 93.82 & 79.41 \\
\hline 5 & $0(50)$ & $0(70)$ & 70.15 & 73.17 \\
\hline 6 & $+(70)$ & $0(70)$ & 45.27 & 75.91 \\
\hline 7 & $-(30)$ & $+(90)$ & 81.84 & 82.99 \\
\hline 8 & $0(50)$ & $+(90)$ & 67.67 & 74.94 \\
\hline 9 & $+(70)$ & $+(90)$ & 44.73 & 69.60 \\
\hline 10 & $0(50)$ & $0(70)$ & 67.54 & 65.90 \\
\hline 11 & $0(50)$ & $0(70)$ & 59.27 & \\
\hline
\end{tabular}




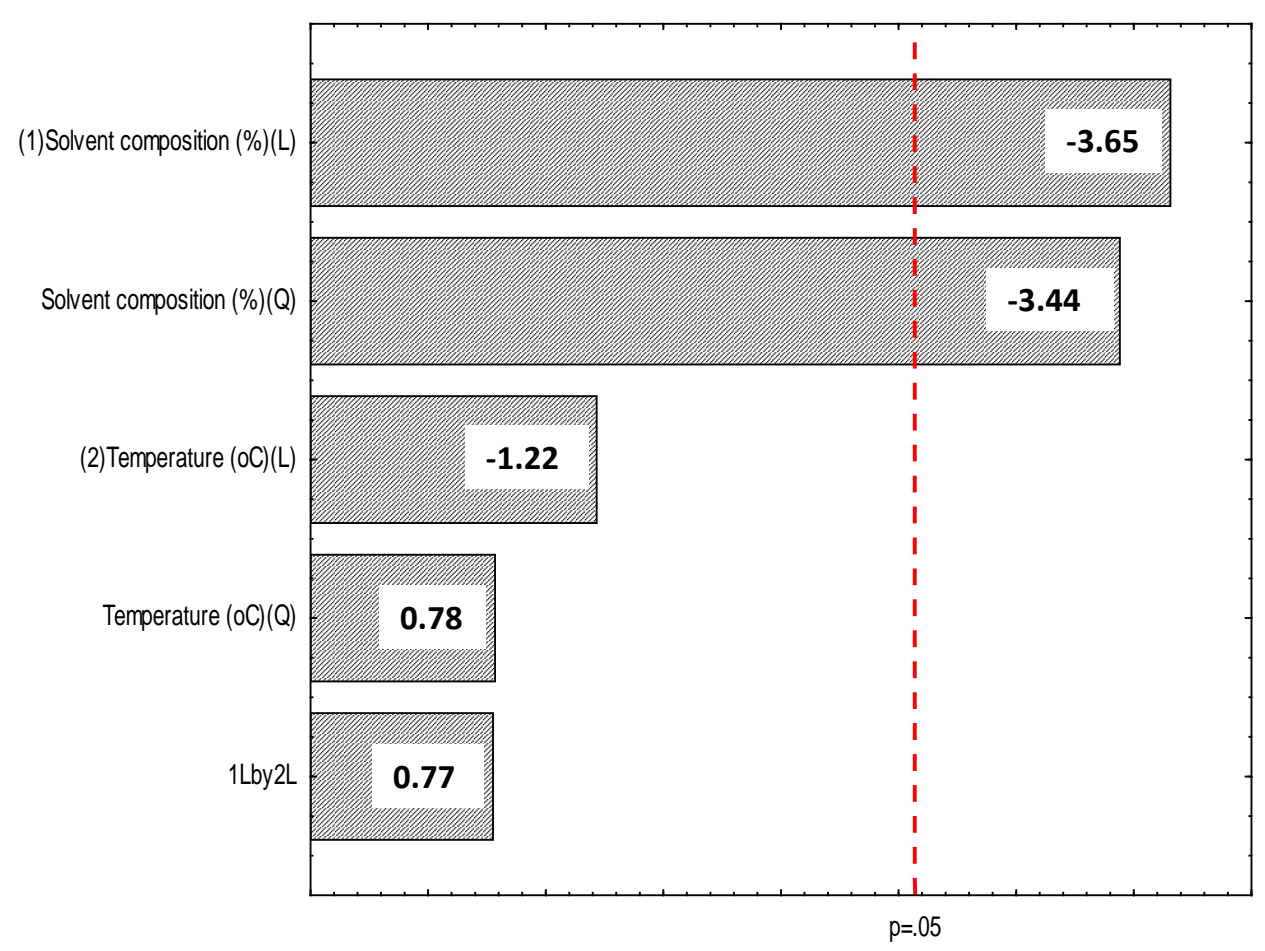

Standardized Effect Estimate (Absolute Value)

Figure 4. Standardized $(\mathrm{P}<0.05)$ main effect Pareto charts for the $3^{2}$ full factorial design for the extraction recoveries in fortified corn sample of a) 2,4-D and b) atrazine.

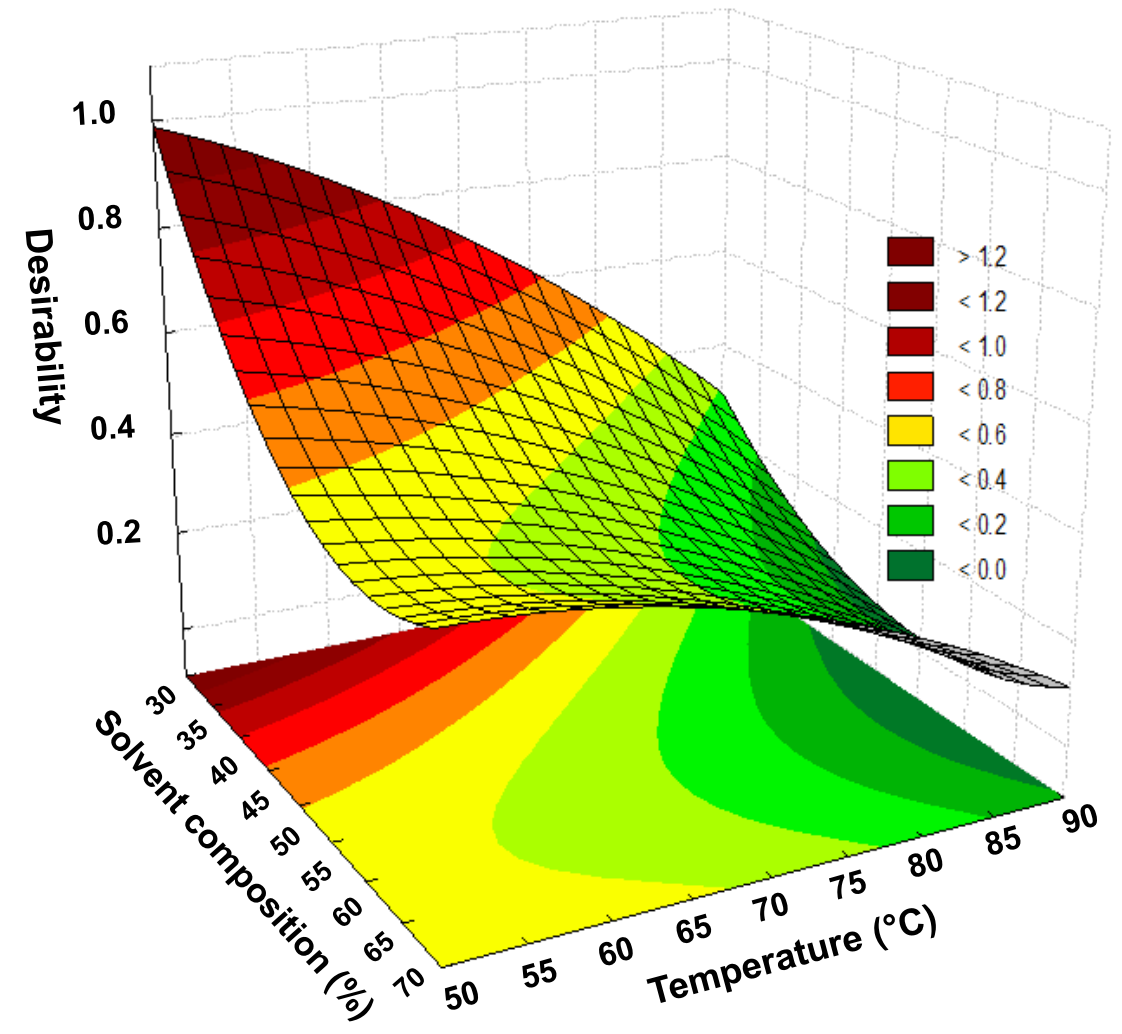

Figure 5. Surface profile using overall desirability as response. 


\section{Analysis of corn samples}

To evaluate the accuracy and applicability of the present method, two corn samples bought at a local market were analyzed. The samples were processed in triplicate following the above-described MAE and on-line SPE-HPLC/UV analysis. The two herbicides in samples were undetectable. The analytical results of the recovery study for each compound at the spiked level of $0.5 \mathrm{mg} \mathrm{kg}^{-1}$ of 2,4-D and atrazine are listed in Table 4. The recoveries of 2,4-D and atrazine were from 82.6 to $98.2 \%$. RSD values were lower than $4.2 \%$. The typical chromatograms of standard solution and spiked sample 1 (S1) are shown in Fig. 6. The results indicated that the method provides good recoveries and reasonable precision for herbicide analysis in corn samples. The limits of detection achieved by on-line SPE-HPLC/UV were below the maximum residue levels established in EU and Codex Alimentarius regulations for 2,4-D and atrazine in corn [6]. The present methodology showed LOD value comparable to that reported by Cunha and Fernandes for the determination of atrazine from corn using QuEChERS and dispersive liquid-liquid microextraction followed by GC-MS analysis [7]. LODs approximately twenty times lower were described for the analysis of triazine compounds in cereal samples using dynamic microwave-assisted extraction (DMAE) combined with solidification of floating organic drop (SFO) and HPLC-UV [22]. HPLC with UV detection was also used for the determination of triazine herbicides in corn samples allowing LODs in the range of 0.74-1.62 $\mu \mathrm{g} \mathrm{kg}^{-1}$ [3]. Ionic liquid-based foam flotation followed by solid phase extraction was used for sample preparation, enrichment and isolation from corn samples. Although some of the published studies showed better analytical performance than that achieved in this work by on-line SPE-HPLC/UV method, exhaustive sample preparation techniques had been applied that involve quite time-consuming multi-step procedures. The procedure proposed here involves sample preparation by microwave assisted extraction method with an extraction time of 20 min followed by automated SPE coupled to HPLC/UV; a reduced solvent usage and improved sample throughput by at least 2-fold was achieved. Furthermore, the time-consuming batch sample pretreatment step was avoided, thus minimizing risks of sample contamination and analyte losses.

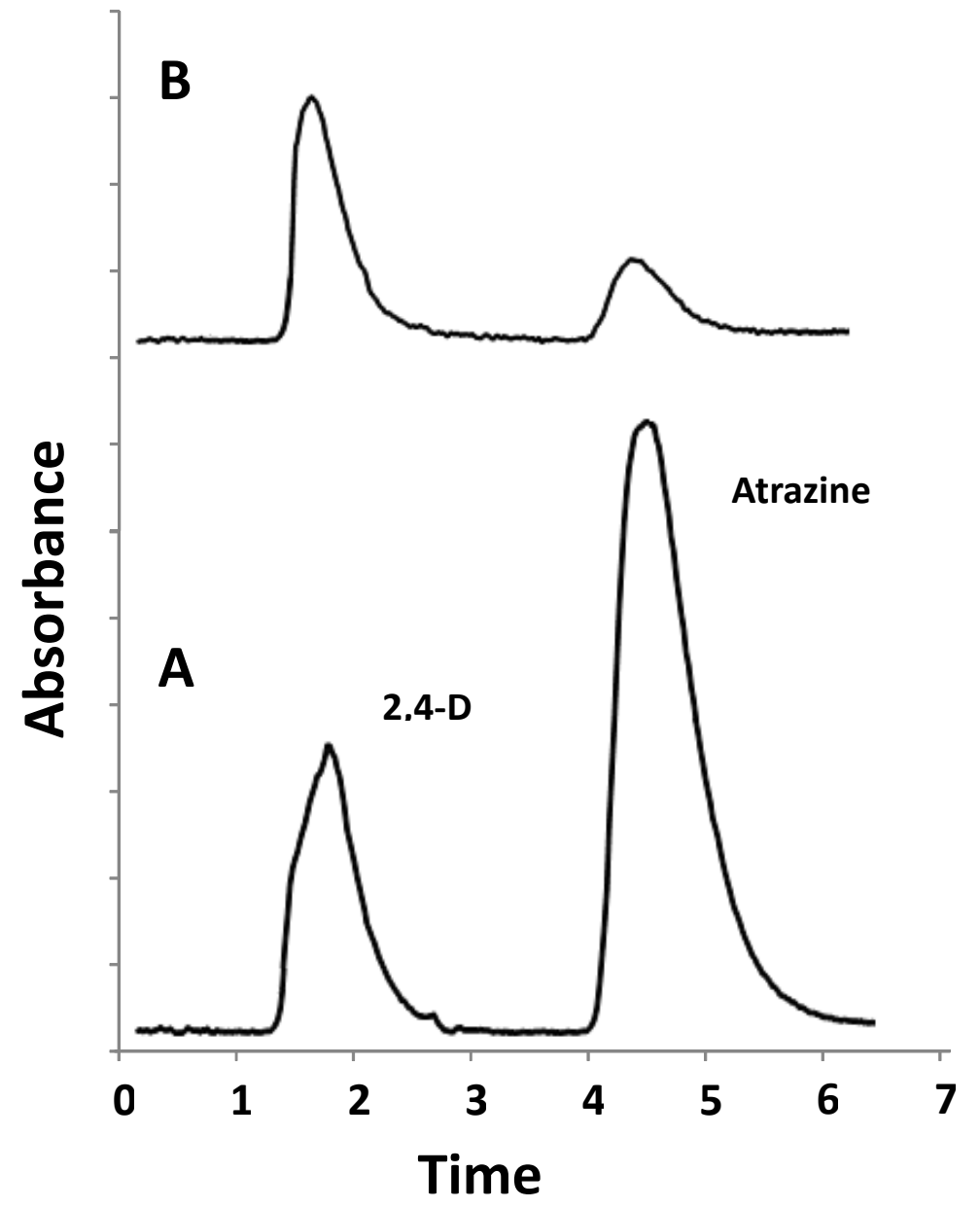

Fig. 6. Chromatograms standard dissolution $\mathrm{A}\left(0.7 \mathrm{mg} \mathrm{L}^{-1}\right)$ and spiked sample $\mathrm{B}\left(0.1 \mathrm{mg} \mathrm{kg}^{-1}\right)$. 
Table 4. Average recoveries (\%) and relative standard deviations (RSD, \%) from two corn samples fortified at $0.5 \mathrm{mg} \mathrm{kg}^{-1}$ level.

\begin{tabular}{|c|c|c|}
\hline Sample & Compound & Recovery (\%) \\
\hline \multirow{2}{*}{ S1 } & $2,4-D$ & $85.4(4.2)$ \\
\cline { 2 - 3 } & atrazine & $97.3(3.1)$ \\
\hline \multirow{2}{*}{ S2 } & $2,4-D$ & $82.6(2.3)$ \\
\cline { 2 - 3 } & atrazine & $98.2(3.4)$ \\
\hline
\end{tabular}

\section{Conclusions}

MAE with extraction solvent $\mathrm{MeOH}: \mathrm{H}_{2} \mathrm{O}\left(30: 70\right.$, v/v) and extraction temperature of $50^{\circ} \mathrm{C}$ followed by on-line SPE-HPLC for the separation and enrichment of the analytes with UV detection was proposed for the determination of 2,4-D and atrazine from corn samples. This method reduced random errors caused by manual sample manipulation. Furthermore, the sample throughput was increased, less sample volume was needed, and the amount of solvents was drastically reduced by using the online-SPE system. The method provided suitable sample clean-up, and acceptable recoveries (82.6-98.2\%), precision, and accuracy. However, the limits of detection achieved enabled only the screening of highly contaminated environmental samples. Aiming the monitoring of herbicides at the concentrations typically described in corn samples, further development will be focused on injection of higher sample volumes to increase the enrichment factors as well as exploitation of more sensitive detectors, including fluorescence and mass spectrometry.

\section{Acknowledgements}

The authors gratefully acknowledge the financial support by grants: CONACYT-México (project CB-177990), and PAICyT-UANL CN384-15. A.S. Santos-Hernández thanks to CONACyT for the granted fellowship.

\section{References}

1. Gaba S.; Gabriel E.; Chadoeuf J.; Bonneu F.; Bretagnolle V. Sci Rep. 2016, 6, 1-10.

2. Islam F.; Wang J.; Farooq M. A.; Khan M.S.S.; Xu L.; Zhu J.; Zhao M.; Munos S.; Li Q. X.; Zhou W. Environ Int. 2018, 111, 332-351.

3. Zhang L.; Wang Z.; Li N.; Yu A; Zhang H. Talanta. 2014,122, 43-50.

4. Barchanska H.; Rusek M.; Szatkowska A. Environ Model Assess. 2012, 184, 321-34.

5. Kock-Schulmeyer M.; Villagrasa M.; Lopez de Alda M.; Cespedes-Sanchez R.; Ventura F.; Barcelo D. Sci Total Environ. 2013, 458-460, 466-476.

6. Handford C. E.; Elliott C. T.; Campbell K. Integr Environ Assess Manag. 2015, 11, 525-536.

7. Cunha S. C.; Fernandes J. O; J Chromatogr A. 2011, 1218, 7748-1757.

8. Barchanska H.; Sajdak M.; Szczypka K.; Swientek A.; Tworek M.; Kurek M. Environ Sci Pollut Res Int. 2017, 24, 644-658.

9. Hou X.; Han M.; Dai X.; Yang X.; Yi S. Food Chem. 2013; 138, 1198-1205.

10. Behbahani M.; Najafi F.; Bagheri S.; Bojdi M. K.; Hassanlou P. G.; Bagheri A. Environ Monit Assess. 2014, 186, 2609-2618.

11. Ji F.; Zhao L.; Yan W.; Feng Q.; Lin J M. J Sep Sci. 2008, 31, 961-968.

12. Romero-Gonzalez R.; Garrido Frenich A.; Martinez Vidal J. L.; Prestes O. D.; Grio S. L. J Chromatogr A. 2011, 1218, 1477-1485.

13. Shamsipur M.; Fattahi N.; Pirsaheb M.; Sharafi K. J Sep Sci. 2012, 35, 2718-2724. 
14. Zhao Q., Li H., Xu Y., Zhang F., Zhao J., Wang L., Hou J., Ding H., Li Y, Jin H., Ding L. J Chromatogr A. 2015, 1376, 26-34.

15. Guo F.; Liu Q.; Shi J. B.; Wei F. S.; Jiang G.B. Talanta. 2014, 119, 396-400.

16. Batista A. D; Chocholous P.; Satinsky D.; Solich P.; Rocha F. R. Talanta. 2015, 133, 142-149.

17. Chavez-Moreno C. A.; Guzman-Mar J. L.; Hinojosa-Reyes L.; Hernandez-Ramirez A.; Ferrer L.; Cerda V. Anal Bioanal Chem. 2012, 403, 2705-2714.

18. Singer H.; Jaus S.; Hanke I.; Luck A.; Hollender J.; Alder A. C. Environ Pollut. 2010, 158, 30543064.

19. Garcia-Ac A.; Segura P. A.; Viglino L.; Furtos A.; Gagnon C.; Prevost M.; Sauve S. J Chromatogr A. 2009, 1216, 8518-8527.

20. Biesaga M.; Jankowska A.; Pyrzyńska K. Microchim. Acta. 2005, 150, 317-322.

21. Wu L.; Song Y.; Xu X.; Li N.; Shao M.; Zhang H.; Yu A.; Yu C.; Ma Q.; Lu C.; Wang Z. Food Chem. 2014, 162, 253-260.

22. Wang H.; Li G.; Zhang Y.; Chen H.; Zhao Q.; Song W.; Xu Y.; Jin H.; Ding L. J Chromatogr A. 2012, 1233, 36-43.

23. Shah J.; Rasul Jan M.; Ara B.; Shehzad F. U. Environ Monit Assess. 2011, 178, 111-9.

24. Wang H.; Ding J.; Ren N. Trends Analyt Chem. 2016, 75, 197-208.

25. Medina L. M.; Mackenzie J.; Bermúdez A. S. Rev Colomb Quim. 1990, 19, 7-14.

26. Kearns J. P.; Wellborn L. S.; Summers R. S.; Knappe D. R. Water Res. 2014, 62, 20-28.

27. Safari M.; Yamini Y.; Tahmasebi E.; Ebrahimpour B. Microchim Acta. 2015, 183, 203-210.

28. Nollet L. M.; Toldrá F. Handbook of seafood and seafood products analysis. CRC Press, 2009.

29. Veggi P. C.; Martinez J.; Meireles M. A. A. In: Fundamentals of microwave extraction. Microwaveassisted extraction for bioactive compounds. Springer, 2012. 15-52.

30. Xiong G.; Tang B.; He X.; Zhao M.; Zhang Z.; Zhang Z. Talanta. 1999, 48, 333-339.

31. Montgomery D.C. Diseño y análisis de experimentos. Limusa Wiley. 2008. 